\title{
(2) OPEN ACCESS \\ Oral S-ketamine effective after deep brain stimulation in severe treatment-resistant depression and extensive comorbidities
}

\author{
Jolien K E Veraart, ${ }^{1,2}$ Jeanine Kamphuis, ${ }^{1}$ Mathis Schlegel, ${ }^{1}$ Robert A Schoevers (1) ${ }^{1,3}$
}

\begin{abstract}
'Department of Psychiatry, University of Groningen, University Medical Centre Groningen, Groningen, The Netherlands

${ }^{2}$ PsyQ Haaglanden, Parnassia Psychiatric Institute, The Hague, The Netherlands

${ }^{3}$ Research School of Behavioural and Cognitive Neurosciences $(B C N)$, University of Groningen, Groningen, The Netherlands
\end{abstract}

Correspondence to

Jolien K E Veraart;

j.k.e.veraart@umcg.nl

Accepted 14 December 2020

Check for updates

(c) BMJ Publishing Group Limited 2021. Re-use permitted under CC BY. Published by BMJ.

To cite: Veraart JKE,

Kamphuis J, Schlegel M,

et al. BMJ Case Rep

2021:14:e238135.

doi:10.1136/bcr-2020-

238135

\section{SUMMARY}

This case report describes successful maintenance treatment with oral S-ketamine in a patient with severe depression, who previously was resistant to electroconvulsive therapy and deep brain stimulation, and who also had comorbid psychotic and obsessive compulsive symptoms.

\section{BACKGROUND}

Treatment resistance in patients with depression is associated with vast losses in quality of life and an increased risk of suicidal ideation and suicide. ${ }^{1}$ Infusions of the N-methyl-D-aspartate receptor antagonist ketamine or the enantiomer S-ketamine have shown rapid antidepressant effects in treatment-resistant depression (TRD). ${ }^{2}$ Recent studies suggest efficacy plus good tolerability of repeated oral ketamine treatment. ${ }^{34}$ Patients with comorbid psychiatric disorders are often excluded from clinical trials, although they may represent the most severe TRD cases. The case presented here suggests that remission of severe TRD with extensive comorbidities can be achieved with repeated administration of oral S-ketamine when electroconvulsive therapy (ECT) and deep brain stimulation (DBS) have been ineffective.

\section{CASE PRESENTATION}

Our patient is a 55-year-old female who presented to our academic centre with severe TRD, comorbid obsessive-compulsive disorder (OCD) and psychotic symptoms (auditory hallucinations). Subsequent treatment strategies, including extensive pharmacotherapy (serotonin-norepinephrine reuptake inhibitors, tricyclic antidepressants and lithium addition), psychotherapies (cognitive behavioural and systemic therapies) and ECT had not significantly improved her situation for over 20 years.

In 2014, she participated in a clinical trial of DBS. She received bilateral implants of four contact electrodes targeting the ventral anterior limb of the internal capsule. ${ }^{5}$ Various adjustments of electrode settings failed to improve her situation, leading to despair and increase in suicidal ideation.

\section{TREATMENT}

Augmentation with generic oral S-ketamine from our hospital pharmacy was initiated after the patient gave written informed consent for off-label 'compassionate use' treatment. Her other medications remained unchanged: venlafaxine $300 \mathrm{mg}$, clozapine $450 \mathrm{mg}$, glycopyrronium $0.7 \mathrm{mg}$ and movicolon daily, plus $5 \mathrm{mg}$ nitrazepam three times per week. DBS settings were kept stable at $3.0 \mathrm{~V}$, pulse width 60 and frequency $180 \mathrm{~Hz}$.

Oral S-ketamine treatment started at $0.5 \mathrm{mg} / \mathrm{kg}$ twice weekly and was titrated to $2.0 \mathrm{mg} / \mathrm{kg}$. Vital signs were stable. Apart from temporary dizziness, no adverse events occurred.

\section{OUTCOME AND FOLLOW-UP}

Evaluation after 6 weeks revealed a decrease in Inventory of Depressive Symptomatology SelfReport (IDS-SR) score from 54 to 30 and Hamilton Depression Rating Scale 17 score from 24 to 6 (figure 1 for IDS-SR scores). The patient reported an overall good response and started to function again in important domains of life. Interestingly, both her auditory hallucinations and obsessive-compulsive symptoms decreased. She currently continues S-ketamine treatment twice weekly at home, and has been in remission for 18 months now. Risks and benefits of prolonged treatment were extensively discussed with the patient. We systematically monitor symptoms and possible adverse effects.

\section{DISCUSSION}

We believe this case illustrates the potential of generic oral S-ketamine in the most severe cases of TRD. The oral S-ketamine showed beneficial effects not only on the depressive symptoms, but also on the disturbing comorbid obsessive-compulsive and psychotic symptoms in this case. Significant improvement in obsessions after ketamine administration in patients with OCD has been reported previously in a small randomised controlled crossover trial. ${ }^{6}$ Patients with psychotic symptoms have been excluded for most clinical trials studying ketamine as a treatment for depression. Ketamine has the potential to induce psychotomimetic effects in healthy subjects and to exacerbate psychotic symptoms in patients with schizophrenia.? However, the psychotic manifestations, such as perceptual abnormalities, disordered thought and dissociation after ketamine administration are transient and seem to be well tolerated, even in patients with psychotic vulnerability. ${ }^{8-10}$ Of note, ketamine is also suggested to be more effective in patients with a higher childhood trauma burden, ${ }^{11}$ which is a known risk factor for the development of TRD and suicide. ${ }^{12}$

Repeated oral S-ketamine was safely combined with other psychiatric drugs and even with the 


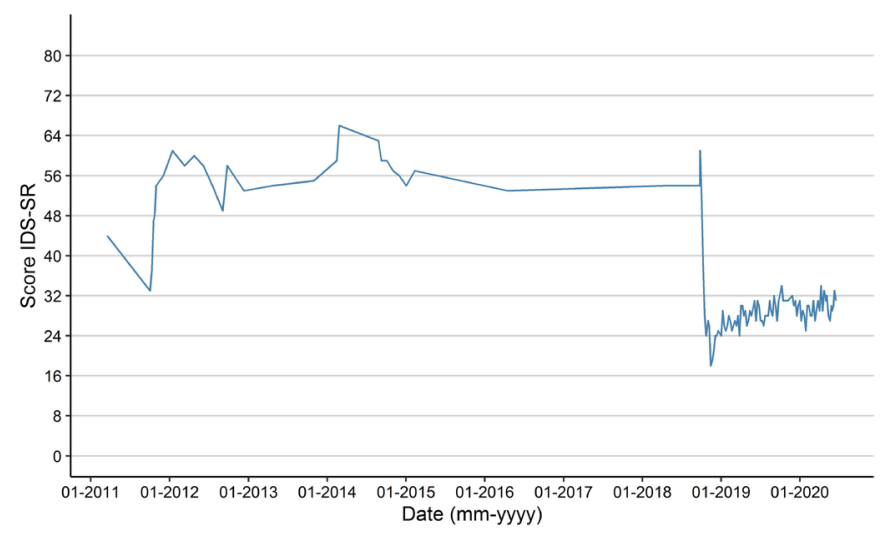

Figure 1 IDS-SR (Inventory of Depressive Symptomatology SelfReport) scores.

experimental neuromodulation treatment of DBS. Safety and tolerability of oral S-ketamine as add-on to standard antidepressants has been previously described in a case series by Paslakis et al. ${ }^{13} \mathrm{~S}$-ketamine augmentation via other routes of administration has also been studied in combination with regular antidepressants and antipsychotics. ${ }^{13-15}$ However, to the best of our knowledge, this is the first paper reporting on S-ketamine administration in a patient with DBS implants.

Given the enormous burden of TRD for patients, we believe trials with (S-)ketamine treatment in patients with extensive comorbidities are both needed and justified, if outcomes are thoroughly monitored over time. Careful monitoring of patients eligible for last resort 'compassionate use' programmes will provide useful information on the treatment potential of (S-) ketamine to relieve suffering and improve quality of life.

\section{Patient's perspective}

Since the ketamine treatment, my mood changed. I am able to enjoy activities again. I started feeling emotions again that I have not felt since my depression started, such as enjoyment, sadness and missing my dog. My obsessive and compulsive symptoms have decreased since this mood improvement; they are still there but I can cope now.

\section{Learning points}

- Maintenance treatment with oral S-ketamine showed long-term beneficial effects in severe treatment-resistant depression (TRD).

- Oral S-ketamine reduced comorbid psychotic symptoms and obsessive-compulsive symptoms in a patient with TRD.

- Oral S-ketamine treatment was safely combined with experimental deep brain stimulation for depression.

Acknowledgements We thank SY Smith-Apeldoorn for thorough revision of the manuscript.
Contributors JKEV: Design, analysis and interpretation of data, drafting, final approval and agreement to be accountable. JK: Analysis and interpretation of data, critically revising, final approval and agreement to be accountable. MS: Design, acquisition and interpretation of data, drafting, final approval and agreement to be accountable. RAS: Conception, acquisition of data, analysis and interpretation of data, drafting, critically revising, final approval and agreement to be accountable.

Funding The authors have not declared a specific grant for this research from any funding agency in the public, commercial or not-for-profit sectors.

Competing interests JKEV received a speaker's honorarium from Janssen, outside the submitted work. RAS has received research funding for two randomised clinical trials with generic oral esketamine from the Netherlands Organisation for Health Research \& Development and the National Health Care Institute, a speaker's fee from Janssen and consultancy fee from Clexio Biosciences, both outside the submitted work.

\section{Patient consent for publication Obtained.}

Provenance and peer review Not commissioned; externally peer-reviewed.

Open access This is an open access article distributed in accordance with the Creative Commons Attribution 4.0 Unported (CC BY 4.0) license, which permits others to copy, redistribute, remix, transform and build upon this work for any purpose, provided the original work is properly cited, a link to the licence is given, and indication of whether changes were made. See: https://creativecommons.org/ licenses/by/4.0/.

\section{ORCID iD}

Robert A Schoevers http://orcid.org/0000-0003-0760-9866

\section{REFERENCES}

1 Smith-Apeldoorn SY, Veraart JKE, Schoevers RA. Definition and epidemiology of treatment resistance in psychiatry. In: Kim YK, ed. Treatment resistance in psychiatry: risk factors, biology and management. Springer Nature Singapore Pte Ltd, 2019: 16-38.

2 Caddy C, Amit BH, McCloud TL. Ketamine and other glutamate receptor modulators for depression in adults. Cochrane Database Syst Rev 2015;23:CD011612.

3 Rosenblat JD, Carvalho AF, Li M, et al. Oral ketamine for depression: a systematic review. J Clin Psychiatry 2019;80:18r12475.

4 Schoevers RA, Chaves TV, Balukova SM, et al. Oral ketamine for the treatment of pain and treatment-resistant depressiont. Br J Psychiatry 2016;208:108-13.

5 Bergfeld IO, Mantione M, Hoogendoorn MLC, et al. Deep brain stimulation of the ventral anterior limb of the internal capsule for treatment-resistant depression: a randomized clinical trial. JAMA Psychiatry 2016;73:456-64.

6 Rodriguez $\mathrm{Cl}$, Kegeles LS, Levinson A, et al. Randomized controlled crossover trial of ketamine in obsessive-compulsive disorder: proof-of-concept. Neuropsychopharmacology 2013;38:2475-83.

7 Lahti AC, Weiler MA, Tamara Michaelidis BA, et al. Effects of ketamine in normal and schizophrenic volunteers. Neuropsychopharmacology 2001;25:455-67.

8 Ajub E, Lacerda ALT. Efficacy of Esketamine in the treatment of depression with psychotic features: a case series. Biol Psychiatry 2018;83:e15-16.

9 Medeiros da Frota Ribeiro C, Sanacora G, Ostroff R. Reply to: ketamine and psychosis history: antidepressant efficacy and psychotomimetic effects Postinfusion. Biol Psychiatry 2017;82:e37.

10 Pennybaker SJ, Luckenbaugh DA, Park LT, et al. Ketamine and psychosis history: antidepressant efficacy and psychotomimetic effects Postinfusion. Biol Psychiatry 2017;82:e35-6.

11 O'Brien B, Lijffijt M, Wells A, et al. The impact of childhood maltreatment on intravenous ketamine outcomes for adult patients with treatment-resistant depression. Pharmaceuticals 2019;12:133.

12 Pompili M, Innamorati M, Lamis DA, et al. The associations among childhood maltreatment, "male depression" and suicide risk in psychiatric patients. Psychiatry Res 2014;220:571-8

13 Paslakis G, Gilles M, Meyer-Lindenberg A, et al. Oral administration of the NMDA receptor antagonist S-ketamine as add-on therapy of depression: a case series. Pharmacopsychiatry 2010;43:33-5.

14 Del Sant LC, Sarin LM, Magalhães EJM, et al. Effects of subcutaneous esketamine on blood pressure and heart rate in treatment-resistant depression. J Psychopharmacol 2020;34:1155-62.

15 Kryst J, Kawalec P, Pilc A. Efficacy and safety of intranasal esketamine for the treatment of major depressive disorder. Expert Opin Pharmacother 2020;21:9-20 
Copyright 2021 BMJ Publishing Group. All rights reserved. For permission to reuse any of this content visit https://www.bmj.com/company/products-services/rights-and-licensing/permissions/

BMJ Case Report Fellows may re-use this article for personal use and teaching without any further permission.

Become a Fellow of BMJ Case Reports today and you can:

- Submit as many cases as you like

- Enjoy fast sympathetic peer review and rapid publication of accepted articles

Access all the published articles

Re-use any of the published material for personal use and teaching without further permission

Customer Service

If you have any further queries about your subscription, please contact our customer services team on +44 (0) 2071111105 or via email at support@bmj.com.

Visit casereports.bmj.com for more articles like this and to become a Fellow 